\title{
Phosphate liquid-phase adsorption removal by calcination dolomite and
}

\section{multi-variables interaction effects}

\author{
Rongtai $\mathrm{Yu}^{1, \mathrm{a}}$, Xiang $\mathrm{Ma}^{1, \mathrm{~b}}$, Yonghui Hong ${ }^{1, \mathrm{c}}$, Zhipeng $\mathrm{Xie}^{2, \mathrm{~d}}$, Changan Wang ${ }^{2, \mathrm{e}}$ \\ 1 School of Materials Science and Engineering, Jingdezhen Ceramic Institute, Jingdezhen, 333001, Jiangxi, \\ PR China; \\ 2 School of Materials Science and Engineering, Tsinghua University, Beijing, 100084, Beijing, PR China \\ ayurongtai518@163.com, bmaxiang@jci.edu.cn, ${ }^{\mathrm{c}} 1656467793 @ q q . c o m$, \\ dxzp@tsinghu \\ a.edu.cn, ${ }^{\mathrm{e}}$ wangca@ tsinghua.edu.cn
}

Key Words: Adsorption, Dolomite, Phosphate, Multi-variables interaction effects

Abstract: An experimental study on the adsorption removal of phosphate onto a natural and cheap dolomite mineral was carried out. The effects of calcination temperature, holding time, initial $\mathrm{pH}$ and dosage on phosphate adsorption were investigated, and multi-variables interaction effects were explorated. The effect of calcination temperature on phosphate adsorption was positive, the removal rate was $99 \%$ at calcination temperature above $800{ }^{\circ} \mathrm{C}$; and a convex curve was observed in the experiment of holding time. The best removal rate was achieved at $\mathrm{pH} 9.0$, and it was suggested that chemisorption was mainly adsorption. In multi-variables interaction effects, the interaction effect between holding time and dosage was significant. Compared with the other factors, the effect of dosage was most significantly on phosphate adsorption.

\section{Introduction}

Phosphorus belongs to the resources which can't be regenerated. However, phosphorus is one of the most important nutrients essential for animal and plant growth. Phosphorus is losing with extensive discharge of phosphate into water bodies, and which play an important role in the lake eutrophication. Therefore, for recycling phosphate, phosphate recovery techniques have been studied in literatures, including crystallization, chemical precipitation and biological techniques. In recent years, some new techniques were reported in literatures, $\mathrm{Xu}$ et $\mathrm{al}^{[1]}$ reported that phosphate was removal by magnesium potassium phosphate; Wang et $\mathrm{al}^{[2]}$ suggested that an electrodialysis technique with struvite reactor could effectively recycle phosphorus; and Huang et $\mathrm{al}^{[3]}$ argued that struvite precipitation technique was an effectively way for phosphate recycling. Although these methods had their own utility, their disadvantages were existed in above mentioned method, such as high cost, complicated operation and precise control the operating conditions.

Adsorption has received increasing attention for elimination of contaminants from wastewaters. The adsorption technique has advantages for performance and low cost over the other techniques, especially for pollutant removal by wetlands. Dolomite, a natural and cheap mineral, consists of calcium, magnesium, carbon and oxygen. Dolomite has a good adsorption performance to phosphate or fluoride for rich of calcium and magnesium. In previous research, these literatures focuses on modification, kinetic and adsorption isotherm of dolomite ${ }^{[4]}$, Interactive effects between modification and adsorption seldom do something deeply.

This research was carried out to investigate the adsorption removal of phosphate from wastewater by adsorption onto calcination dolomite, and the interactive effect, including calcination temperature, holding time, dosage and initial $\mathrm{pH}$, was studied. Further insights on the mechanism of adsorption (chemisorption or physisorption) and nature of the adsorption process were examined by XRD and FTIR. 


\section{Materials and methods}

\subsection{Chemicals}

The domolite used in this study was obtained from Jiangxi Reagent Plant, the partical size of domolite was less than $0.075 \mathrm{~mm}$ (the standard sieve number 200). All chemical agents were used with analytical grade, and simulated wastewater was used for phosphate adsorption removal by calcination domolite, the concentration of phosphate was $150 \mathrm{mg} / \mathrm{L}$. Ammonium molybdate spectrophotometric method (GB 11893-89, China) was used for the determination of phosphate concentration. Batch experiments of phosphate adsorption removal were investigated by six-one-electromotive stirrer.

\subsection{Thermal modification of dolomite}

To study the effect of calcination temperature and time on the dolomite, the conditions of calcination dolomite were performed as follows: calcination temperature was from $500{ }^{\circ} \mathrm{C}$ to $1000{ }^{\circ} \mathrm{C}$, holding time was from 0.5 to 4 hour. The calcination dolomite at different temperature and holding time were collected.

\subsection{Adsorption batch experiments}

The effect of $\mathrm{pH}$, dosage, calcination temperature and holding time on phosphate adsorption removal was studied. First, calcination dolomite was added to the simulate wastewater (200 ml, $\mathrm{PO}_{4}{ }^{3-}$ concentration $150 \mathrm{mg} / \mathrm{L}$ ); Second, mixed solution was agitated for $60 \mathrm{~min}$ at $\mathrm{pH} 9.5$ (except $\mathrm{pH}$ experiment), and the calcination dolomite of $600{ }^{\circ} \mathrm{C}$ was used for holding time experiment, the dolomite used in others experiments was calcination at $800{ }^{\circ} \mathrm{C}$ for $2 \mathrm{~h}$; Stirrer rotation speed was $200 \mathrm{r} / \mathrm{min}$, and let it settle for $30 \mathrm{~min}$ after $60 \mathrm{~min}$ adsorption time; All but one of the dosage experiment and the dosage was $0.5 \mathrm{~g}$; Finally, the precipitation was collected, and dried in an oven at $40{ }^{\circ} \mathrm{C}$ for $48 \mathrm{~h}$, the concentration of phosphate in the supernatant was measured.

\subsection{Multi-variables interaction effects}

The effect of $\mathrm{pH}$, dosage, calcination temperature and holding time were investigated in above. However, the interaction effects between the variables would be possible. Response surface methodology (RSM), as an optimization of analytical method, was used to analyze multi-variables interaction effects. Box-behnken, symmetrical experimental designs was used to determinate experiment parameter, a series of responses of several variables were examined.

\section{Results and Discussion}

\subsection{Effect of calcination temperature and holding time on phosphate removal}

To investigate the effect of calcination temperature and holding time on the phosphate adsorption removal by dolomite, experiments were carried out with varying calcination temperature and holding time from 500 to $1000{ }^{\circ} \mathrm{C}$, and 0.5 to $4 \mathrm{~h}$, respectively; the initial concentration of phosphate was $150 \mathrm{mg} / \mathrm{L}$; stirrer rotation speed was $200 \mathrm{r} / \mathrm{min}$, and mixing time was $60 \mathrm{~min}$. The results were showed in Figure 1. As could be seen from the Figure, the adsorption of phosphate onto the suface of dolomite was changed with different calcination temperature and holding time, phosphate removal rate was increased with the rise of calcination temperature, which was close to $99 \%$ when calcination temperature was above $800{ }^{\circ} \mathrm{C}$ with holding time $2 \mathrm{~h}$ (Figure $1 \mathrm{~A}$ ); phosphate adsorption ratio hardly increased with temperature increased successively. While the trend of the phosphate adsorption curve was different with holding time, as showed in Figure $1 \mathrm{~B}$, the phosphate adsorption showed a downward trend after the first rise; phosphate removal rate was close to the peak with holding time $2 \mathrm{~h}$, which had dramatically decreased with holding time increased successively. Therefore, the optimum calcination temperature was $800^{\circ} \mathrm{C}$, and holding time was $2 \mathrm{~h}$ 
in single-factor test.

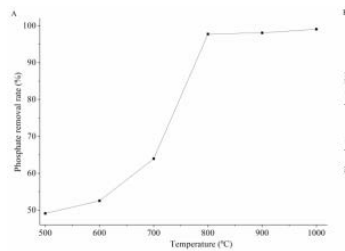

Figure 1 The effect of temperature and time on phosphate removal by modification of dolomite. A calcination temperature; $\mathrm{B}$ holding time

As reported in the literatures ${ }^{[5]}$, the phosphate adsorption removal process was controlled by chemical bonding or chemisorption as well as an intraparticle diffusion mechanism process. Dolomite occurred as a two-step process when it heated in an oven, the reaction equation was described as follows ${ }^{[6]}$.

$$
\begin{aligned}
& \mathrm{CaMg}\left(\mathrm{CO}_{3}\right)_{2}=\mathrm{MgO}+\mathrm{CaCO}_{3}+\mathrm{CO}_{2} \\
& \mathrm{CaCO}_{3}=\mathrm{CaO}+\mathrm{CO}_{2}
\end{aligned}
$$

The two step decomposition of dolomite was switched by heating temperature, holding time or atmosphere, but the precise mechanism of dolomite decomposition was no general agreement. As reported by Sasaki ${ }^{[7]}$, dolomite would be decomposed into $\mathrm{MgO}$ and $\mathrm{CaCO}_{3}$ first, and then $\mathrm{CaCO}_{3}$ decomposed into $\mathrm{CaO}$ with increased heating temperature to $700-900{ }^{\circ} \mathrm{C}$. When calcination temperature below $800{ }^{\circ} \mathrm{C}$, dolomite was possible dissociated into magnesium and calcium carbonates, or which decay into the mixture of carbonate and a small amount of oxides. However, calcium carbonates, as well as magnesium carbonates have weak efficiencies in removing phosphate; while oxides, in contrast, have good efficiency of phosphate removal. As showed in Figure $1 \mathrm{~A}$, magnesium and calcium oxides were formed when heating temperature was above $800{ }^{\circ} \mathrm{C}$, the phosphate adsorption removal rate was dramatically increased accordingly. The incomplete decomposition of dolomite would be possible when calcination time was less than $2 \mathrm{~h}$, the crystal structure were arranged orderly with the extension of holding time, therefore, the phosphate adsorption was increased at first and then descend with the calcination time extended (Figure $1 \mathrm{~B}$ ).

\subsection{Effect of $\mathrm{pH}$ and dosage}

The effect of $\mathrm{pH}$ on the phosphate adsorption removal by calcination dolomite was studied. The phosphate removal rate was decreased slightly with $\mathrm{pH}$ value increasing when the $\mathrm{pH}$ value was lower than 9.0, which was from $98.7 \%$ to $95.6 \%$ with $\mathrm{pH} 7.5$ to 8.5 . The optimum value of phosphate removal rate was $99.3 \%$ when $\mathrm{pH}$ value was 9.0 , and the curve declined slightly with $\mathrm{pH}$ steadily rising.

Previous studies have suggested that the concentrations of $\mathrm{Ca}^{2+}, \mathrm{PO}_{4}{ }^{3-}$ and $\mathrm{OH}^{-}$were changed with different $\mathrm{pH}$ value ${ }^{[8]}$. The release rate of $\mathrm{Ca}^{2+}$ in the dolomite was decreased with increasing initial $\mathrm{pH}$, and orthophosphate compound was changed with different $\mathrm{pH}$, including $\mathrm{H}_{3} \mathrm{PO}_{4} \Rightarrow \mathrm{H}_{2} \mathrm{PO}_{4}^{-} \Rightarrow \mathrm{HPO}_{4}^{2-} \Rightarrow \mathrm{PO}_{4}^{3-}$ with increasing $\mathrm{pH}$. The mechanism of dolomite adsorption included physical adsorption, ion exchange and chemisorption ${ }^{[9]}$. The chemisorption was the predominant mechanism in phosphate adsorption by dolomite, calcium phosphate precipitation was formed in higher $\mathrm{pH}$ value. The release rate of $\mathrm{Ca}^{2+}$ in the dolomite was increased with lower $\mathrm{pH}$ value, and $\mathrm{H}_{2} \mathrm{PO}_{4}{ }^{-}$and $\mathrm{HPO}_{4}{ }^{2-}$ were dominant phosphate species at $\mathrm{pH}<4$, the physical adsorption of electrostatic attraction was the predominant mechanism. The adsorption abilities of physical adsorption was reduced with the increase in $\mathrm{pH}$ value, but the amount of calcium phosphate precipitation was increased, the reason was that $\mathrm{PO}_{4}{ }^{3-}$ was the predominant phosphate species with 
the increase of $\mathrm{pH}$, and $\mathrm{Ca}^{2+}$ would be reacted with $\mathrm{PO}_{4}{ }^{3-}$ to form calcium phosphate. That was to say, the disadvantage of phosphate adsorption included the decrease of $\mathrm{Ca}^{2+}$ release rate with the $\mathrm{pH}$ value increasing; at the same time, the amount of $\mathrm{OH}^{-}$ion was increased with $\mathrm{pH}$ increasing, which would be competed with target $\mathrm{PO}_{4}{ }^{3-}$ ions for positive sites on the adsorbent surface. However, $\mathrm{Ca}_{3}\left(\mathrm{PO}_{4}\right)_{2}$ would be formed with the amount of $\mathrm{PO}_{4}{ }^{3-}$ ions increasing. The adsorption abilities of physical adsorption were decreased with $\mathrm{pH}$ value increasing, while those of the chemisorption were increased. Therefore, the optimal $\mathrm{pH}$-value existed in phosphate adsorption by dolomite. In this study, the phosphate adsorption removal rate was the best at $\mathrm{pH} 9.0$, it showed that the chemisorption was the predominant mechanism in phosphate adsorption by calcination dolomite.

The effect of adsorbent dosage on adsorption of phosphate onto calcination dolomite was carried out with initial phosphate concentration of $150 \mathrm{mg} / \mathrm{L}$ and varying adsorbent dosage from 0.1 to $2.0 \mathrm{~g}$. The result showed that phosphate adsorption efficiency by calcination dolomite was increased with increased adsorbent amount. The phosphate removal rate was above 99\% when the dosage was raised more than $0.5 \mathrm{~g}$. However, the phosphate removal rate was almost the same with increased the dosage successively. Excessive amounts of calcination dolomite can provide the large number of vacant adsorption sites and the greater surface area, which would benefit phosphate adsorption. However, excessive number of vacant adsorption sites and the greater surface area was not effective when almost all phosphate was removed. In this study, the best dosage on adsorption phosphate onto calcination dolomite was $0.5 \mathrm{~g}$.

\subsection{Multi-variables interaction effects}

In above study, the effects of calcination temperature, holding time, initial $\mathrm{pH}$ and dosage on phosphate adsorption by dolomite were investigated. However, the results were achieved under the conditions of others variables unchanged. The interaction effects would be possible existed, the interaction effects of multi-variables could be investigated by Response Surface Methodology, a very popular for optimization studies in recent years. The effects of calcination temperature, holding time, initial $\mathrm{pH}$ and dosage on phosphate adsorption were studied, the parameters were $500-1000{ }^{\circ} \mathrm{C}$, 0.5-4 h, 7.5-10.0 and 0.1-2 g, respectively. The results were showed in Figure 2 and Table 1. As showed in table 1, the model F-value of 15.7 implies the model was significant, there was only a $0.01 \%$ chance that a "Model F-value" this large could occur due to noise. Values of "p value" less than 0.05 indicated model terms were significant. In this case $A, B, D, B D, A^{2}, B^{2}, D^{2}$ were significant model terms.

The response surface corresponding to the second-order model (Figure 2) showed that, for calcination temperature, phosphate adsorption removal rate increased initially, reached a maximum at intermediate holding time, $\mathrm{pH}$ value and dosage, and then decreased at high holding time, $\mathrm{pH}$ value and dosage (Figure $2 \mathrm{~A}, \mathrm{~B}$ and $\mathrm{C}$ ). This were the results of a negative calcination temperature vs holding time, calcination temperature vs $\mathrm{pH}$ value and calcination temperature vs dosage interaction, and a negative concentration quadratic coefficients were observed (Table 1). However, between dosage vs holding time, $\mathrm{pH}$ value vs holding time and dosage vs $\mathrm{pH}$ value, a different behavior were observed (Figure $2 \mathrm{D}, \mathrm{E}$ and F). Phosphate adsorption removal rate increased initially, reached a maximum at intermediate dosage, holding time and $\mathrm{pH}$ value; on the contrary, for opposite variables, the trend of phosphate removal curve were the same, the curves were like a convex lens. This were the results of a negative calcination dosage vs holding time and dosage vs $\mathrm{pH}$ value, and a negative concentration quadratic coefficient were observed except holding time vs $\mathrm{pH}$ value. According to the results of analysis by Response Surface Methodology (Figure 2), the interaction effects between holding time vs dosage was significant, which were existent, but not significant between calcination temperature vs holding time and calcination temperature vs dosage, the interaction effects between calcination temperature vs $\mathrm{pH}$ value, holding time vs $\mathrm{pH}$ value and 
$\mathrm{pH}$ value vs dosage were the weakest.

In significant interaction effect factors, there was a higher increased in phosphate adsorption with holding time at intermediate dosage, this was due to the fact that the most significant factor was dosage, and its effect was positive. However, between calcination temperature vs holding time and calcination temperature vs dosage, phosphate adsorption removal rate was increased higher at intermediate holding time or dosage than that of at intermediate calcination temperature, it showed that the effects of holding time and dosage were significant between calcination temperature vs holding time or calcination temperature vs dosage. Therefore the most significant was dosage.
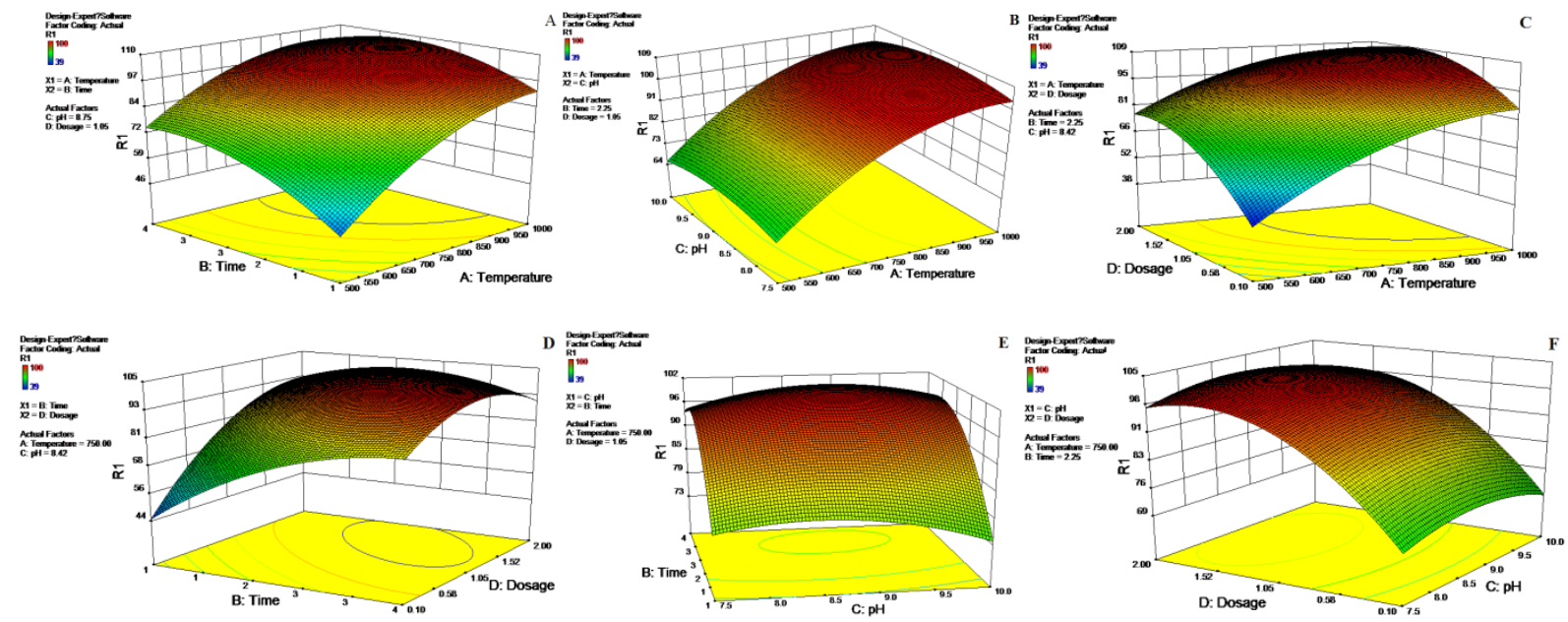

Figure 2 The interaction effects of temperature vs time, $\mathrm{pH}$ and dosage; $\mathrm{pH}$ vs time and dosage; dosage vs time.

\subsection{Characterization of adsorption}

The adsorption performance of domolite was measured at different calcination temperature, and XRD patterns and FTIR were analyzed for adsorption mechanism. As showed in Figure $3 \mathrm{~A}$, the main components were dolomite after calcination $\left(500{ }^{\circ} \mathrm{C}\right)$, the relative intensity of $\mathrm{X}$ ray diffraction peak of dolomite has weaken step by step or gone with calcination temperature increased (Figure $3 \mathrm{~A}$ ). The lattice planes of 015 and 113 were disappeared when calcination temperature was above $800{ }^{\circ} \mathrm{C}$, and the phases were converted into $\mathrm{MgO}$ and $\mathrm{CaO}$. However, these collected precipitates (after adsorbed phosphate by calcination dolomite at $1000{ }^{\circ} \mathrm{C}$ ) were tested by XRD, the diffraction peak of $\mathrm{CaO}$ was disappeared with $\mathrm{MgO}$ and $\mathrm{SiO}_{2}$ diffraction peak relative intensity (impurities) to decrease. These phenomena indicated that amorphous $\mathrm{Ca}_{3}\left(\mathrm{PO}_{4}\right)_{2}$ was first formed. And under the same conditions, $\mathrm{NH}_{4} \mathrm{Cl}$ was added with the mole ratio of $\mathrm{N}: \mathrm{P}$ of $1: 1$, the dosage of dolomite and $\mathrm{pH}$ value was the same, the results showed that the diffraction peak of $\mathrm{CaCO}_{3}$ was observed and $\mathrm{MgO}$ was disappeared. That was, amorphous struvite would be formed by added $\mathrm{NH}_{4} \mathrm{Cl}$. In conclusion, chemisorption was the main mechanism in phosphate adsorption by calcination dolomite.

Also FTIR results confirmed the signals to assign to $\mathrm{OH}^{-}, \mathrm{CO}_{3}{ }^{2-}$ and $\mathrm{PO}_{4}{ }^{3-}$ in dolomite at different conditions (Figure $3 \mathrm{~A}, \mathrm{~B}, \mathrm{C}, \mathrm{D}$ and $\mathrm{E}$ ), with characteristic bands of $\mathrm{v}_{\mathrm{s}}\left(\mathrm{OH}^{-}\right)$at 3600-3700 $\mathrm{cm}^{-1}, \mathrm{v}_{\mathrm{s}}\left(\mathrm{CO}_{3}{ }^{2-}\right)$ at $2500-3021 \mathrm{~cm}^{-1}, \mathrm{v}_{\mathrm{s}}\left(\mathrm{CO}_{3}{ }^{2-}\right)$ at about $1817 \mathrm{~cm}^{-1}, \mathrm{v}_{\mathrm{as}}\left(\mathrm{CO}_{3}{ }^{2-}\right)$ at about $1463 \mathrm{~cm}^{-1}$, $\mathrm{V}_{\mathrm{s}}\left(\mathrm{PO}_{4}{ }^{3-}\right)$ at about $1049 \mathrm{~cm}^{-1}, \omega\left(\mathrm{CO}_{3}{ }^{2-}\right)$ at about $882 \mathrm{~cm}^{-1}$ and $\delta_{\mathrm{s}}\left(\mathrm{CO}_{3}{ }^{2-}\right)$ at about $730 \mathrm{~cm}^{-1}$. The relative intensity of $\mathrm{CO}_{3}{ }^{2-}$ was decreased with temperature increased, and the peaks from 1800-3100 $\mathrm{cm}^{-1}$ were disappeared with temperature above $1000{ }^{\circ} \mathrm{C}$, these peaks were assigned to $\mathrm{CO}_{3}{ }^{2-}$ group. These phenomena showed that the dolomite would have been derived into $\mathrm{CaO}$ and $\mathrm{MgO}$ at relatively high temperatures. The relative intensity of $\mathrm{OH}^{-}$peak was increased with temperature increased, which benefited the attraction of phosphate. A shoulder existed around 1500 $\mathrm{cm}^{-1}$, which could be attributed to the adsorption of $\mathrm{CO}_{2}$ to the surface of $\mathrm{MgO}$ and $\mathrm{CaO}^{[7]}$ (Figure 3 
$\mathrm{C}$ and D). The peak of $\mathrm{PO}_{4}{ }^{3-}$ was observed in the precipitates after adsorbed phosphate (Figure $3 \mathrm{D}$ ). However, the relative intensity of $\mathrm{PO}_{4}{ }^{3-}$ was decreased and the amount of $\mathrm{CO}_{3}{ }^{2-}$ peaks were increased by added ammonium chloride during the process of adsorption phosphate. These results were further verified the XRD’s results.
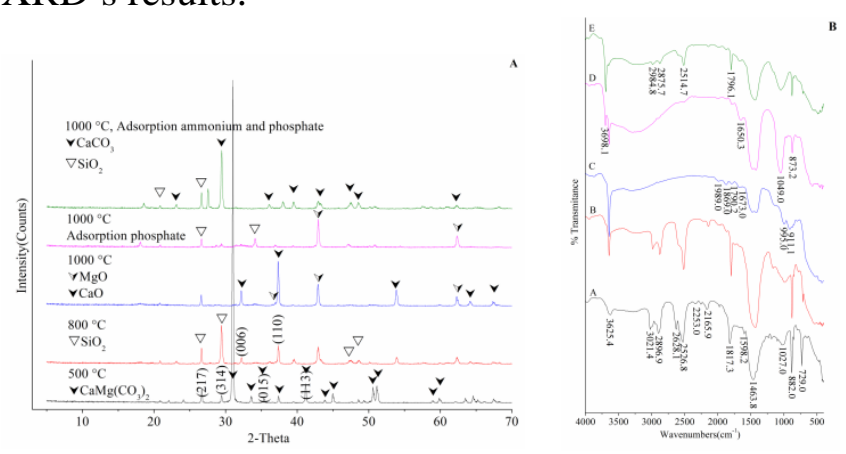

Figure $3 \mathrm{XRD}$ and FTIR of dolomite at different conditions. A calcined dolomite at $500{ }^{\circ} \mathrm{C}$ for $2 \mathrm{~h}$; B calcined dolomite at $800{ }^{\circ} \mathrm{C}$ for $2 \mathrm{~h}$; C calcined dolomite at $1000{ }^{\circ} \mathrm{C}$ for $2 \mathrm{~h}$; D the precipitation of phosphate adsorption by calcined dolomite at $1000{ }^{\circ} \mathrm{C}$ for $2 \mathrm{~h}$; E the precipitation of phosphate and ammonium simultaneous adsorption by calcined dolomite at $1000^{\circ} \mathrm{C}$ for $2 \mathrm{~h}$.

\section{Conclusions}

Thermal modification of dolomite was examined for the adsorption of phosphate from wastewater, and the interactive effects between modification and adsorption were investigated. The adsorption removal of phosphate was increased with calcination temperature increased, the removal rate of phosphate was $99 \%$ when calcination temperature was above $800{ }^{\circ} \mathrm{C}$; while which showed a downward trend after the first rise with the extension of holding time. The maximum adsorption efficiency was achieved at $\mathrm{pH}$ 9.0, and the chemisorption was the predominant mechanism in phosphate adsorption. The best dosage on adsorption phosphate onto calcination dolomite was $0.5 \mathrm{~g}$. The interaction effect between holding time and dosage was significant, while others were the weakest; Compared with the other factors, the effect of dosage was most significantly on phosphate adsorption.

\section{References}

[1] Xu K. N., Li J. Y., Zheng M., Zhang C., Xie T., Wang C. W. The precipitation of magnesium potassium phosphate hexahydrate for $\mathrm{P}$ and $\mathrm{K}$ recovery from synthetic urine. Water Research, 2015, 80, 71-79.

[2] Wang X. L., Zhang X., Wang Y. M., Du Y. X., Feng H. Y., Xu T. W. Simultaneous recovery of ammonium and phosphorus via the integration of electrodialysis with struvite reactor. Journal of Membrane Science, 2015, 490, 65-71.

[3] Huang H. M., Huang L. Y., Zhang Q. R., Jiang Y., Ding L. Chlorination decomposition of struvite and recycling of its product for the removal of ammonium-nitrogen from landfill leachate. Chemopphere, 2014, 136, 289-296.

[4] Liu X. Y., Xiang L. C., Song Y. H., Qian F., Meng X. G. The effects and mechanism of alkalinity on the phosphate recovery from anaerobic digester effluent using dolomite lime. Environmental Earth Sciences, 2015, 73, 5067-5073.

[5] Karaca S., Gürses A., Ejder M., Açıyıldız M. Kinetic modeling of liquid-phase adsorption of phosphate on dolomite. Journal of Colloid and Interface Science, 2004, 277, 257-263.

[6] Karaca S., Gürses A., Ejder M., Açıkyıldız M. Adsorption removal of phosphate from aqueous solutons using raw and calcinated dolomite. Journal of Hazardous Materials, 2006, B128, 273-279.

[7] Sasaki K., Qiu X. H., Hosomomi Y., Moriyama S., Hirajima T. Effect of natural dolomite calcination temperature on sopption of borate onto calcined products. Microporous and Mesoporous Materials, 2013, 171, 1-8.

[8] Ayoub M., Mehawej M. Adsorption of arsenate on untreated dolomite powder. Journal of Hazardous Materials, 2007, 148, 259-266. 
[9] Ivanets A. I., Kitikova N. V., Shashkova I. L., Oleksiienko O. V., Levchuk I., Sillanpää M. Removal of Zn ${ }^{2+}$, $\mathrm{Fe}^{2+}, \mathrm{Cu}^{2+}, \mathrm{Pb}^{2+}, \mathrm{Cd}^{2+}, \mathrm{Ni}^{2+}$ and $\mathrm{Co}^{2+}$ ions from aqueous solutions using modified phosphate dolomite. Journal of Environmental Chemical Engineering, 2014, 2, 981-987. 